\title{
6 Religion, law and COVID-19 in South Africa
}

\author{
Helena Van Coller and Idowu A. Akinloye
}

\section{Introduction}

This chapter appraises the state regulatory response in containing the spread of the new coronavirus disease (COVID-19) in light of the constitutionally guaranteed right to freedom of religion ${ }^{1}$ in South Africa. The increased complaints (Chothia, 2020b; Pillay, 2020; Tsotetsi, 2020) and lawsuits ${ }^{2}$ challenging the impact of the regulatory measures on the flourishing of religious freedom in South Africa heighten the need for the appraisal. According to the World Health Organization (WHO, 2020a), the COVID-19 is a deadly virus that was first identified in Wuhan, China in December 2019. It is said that the virus causes a contagious respiratory disease that spreads through physical contact. On 30 January 2020, the WHO declared the outbreak of the virus as a public health emergency of international concern, and on 11 March 2020 characterized it as a pandemic (WHO, 2020b). As of 2 June 2021, 172,159,531 infected cases have been reported worldwide and 3,696,931 reported deaths (Worldometer, 2021)

For almost a year of its existence, no scientifically proven cure or efficacious treatment was found to heal anyone who contracted the virus. Even now that some vaccines said to be of probable cure to the spread of the virus have been discovered in some countries like in the United States and the United Kingdom, as at early February 2021, South Africa has not started vaccinating (Mwai, 2021). Accordingly, following the advice from health specialists, the South African government, like most other countries, came up with radical measures to reduce the rate of transmission, impact and deaths arising from the virus. Some of these measures are backed by regulations (hereafter, "lockdown regulations") with an attendant effect of fine and imprisonment for their violation (Chothia, 2020a).

An apparent effect of the lockdown regulations is that they restrict the constitutionally guaranteed human rights, including the rights to freedom of movement, freedom of association, freedom of religion and the right to human dignity, among others. Possibly due to the widely held view of South Africans' religiosity, the restriction touching on religious freedom appears to have elicited much public debate. Whilst some members of the public 
welcome the regulations and legal restrictions (Swain, 2020a), others took serious exceptions to some of the regulatory measures, particularly the provisions of the lockdown regulations that ban religious gatherings. Similarly, the South African courts have delivered conflicting rulings in a number of lawsuits that challenged the legality and constitutionality of the ban of religious gathering in an attempt to curb the spread and the numbers of death arising from the virus. The lockdown regulations and their effects on all spheres of human rights may not be effectively evaluated given the limited scope of this chapter and the specific focus of this book. Against the backdrop of the above, this chapter, by using a doctrinal research approach through analysis of literature, statutes and case examples, will evaluate the state regulations enacted to curb the spread of the COVID-19 in South Africa vis-à-vis the constitutional provisions protecting freedom of religion in the country. The primary essence of the evaluation is to determine the constitutional justification of the regulations.

The chapter is structured as follows. After the introduction, it briefly examines the constitutional framework for the protection of the right to freedom of religion in South Africa. Thereafter, some of the provisions of the lockdown regulations that impact on freedom of religion are highlighted. This is followed by an examination of the responses of the religious groups to the regulations. In this section, the opinions of public commentators as well the court rulings were analysed to determine the justification of the regulatory measures in light of the constitutional limitation to human rights, and thereafter, the summary is made and the conclusion is drawn. From the analysis made, the chapter observes that legislative wise, South Africa was clearly not prepared for the pandemic because the government had to hurriedly enact regulations without adequate consultations or planning. It argues that although parts of the regulations that provide for the total or partial ban of religious gatherings in the wake of the outbreak of the COVID-19 may have increased the suffering and violates the rights of most South Africans, they are permissible limitations of religious freedom.

\section{Legal framework for freedom of religion in South Africa}

Freedom of religion is a recognised human right that means different things to different people. This is perhaps because the scope of what it entails varies between states, religions, individuals and legal instruments (Evans, 2001; Sullivan et al., 2015). What appears to gain consensus, however, is that freedom of religion would imply a state's duty to refrain from interfering in an individual or community's pursuit of a chosen religious belief; a right to choose and change one's religion without force and coercion, including the freedom to manifest and practise the religion individually or in fellowship with other believers. The importance of the protection of freedom of religion as a fundamental human right has been widely acknowledged as crucial for the development of an individual's self-definition and the promotion 
of democratic pluralism within society. It is regarded by some as 'the most sacred of all freedoms (Robertson, 1991; Ouashigah, 2014).

South Africa has given constitutional recognition to the protection of the right. Section 15(1) of the South African Constitution 1996 (the Constitution) provides: "Everyone has the right to freedom of conscience, religion, thought, belief and opinion." Chaskalson P, in $S$ v Lawrence (1997) described the scope of this provision as the

right to entertain such religious beliefs as a person chooses, the right to declare such religious beliefs openly and without fear of hindrance or reprisal, and the right to manifest religious belief by worship and practice or by teaching and dissemination.

(Van der Schyff, 2003; Govindjee, 2016)

It is submitted that the full ambit of this right can only be ascertained when section 15 of the Constitution is read conjunctively with sections $9(3),{ }^{3} 31,{ }^{4}$ and $185^{5}$ of the Constitution (Constitution of the Republic of South Africa, 1996). The combination of the above provisions protects individual and group religious autonomy, equality of all religions, and non-discrimination on the basis of religion. It further protects the rights to belong to any religion; change one's religion; manifest and propagate one's religion either in public or in private or either alone or in community with others.

The right which is majorly violated by the lockdown regulations is the right to manifest one's belief in community with others-religious gathering that is guaranteed in terms of sections 17 and 18 of the Constitution (Constitution of the Republic of South Africa, 1996). This right is at the heart of the freedom of religion because it underscores the collective group or institutional right to freedom of religion. Dinstein rightly argues, "Freedom of religion, as an individual right, may be nullified unless complemented by a collective human right of the religious group to construct the infrastructure making possible the full enjoyment of that freedom by individuals" (Dinstein, 1992; Govindjee, 2016).

Freedom of religion is, however, not absolute in the Constitution. The state may be obliged in certain cases to limit a fundamental right including the right to freedom of religion. But in terms of section 36 of the Constitution, where the state is to limit any of the constitutionally guaranteed rights, such limitation must be reasonable and justifiable in an open and democratic society based on human dignity, equality, and freedom. Usually, to determine the validity of a limitation, the court will delve into a limitation analysis involving "... the balancing of means and ends." This will involve an analysis of all relevant considerations

to determine the proportionality between the extent of the limitation of the right considering the nature and importance of the infringed right, on the one hand, and the purpose, importance and effect of the 
infringing provision, taking into account the availability of less restrictive means available to achieve that purpose.

(Minister of Home Affairs v NICRO, 2005)

As noted previously, some of the provisions of the lockdown regulations limit the freedom of religion. The next section will highlight some of these provisions.

\section{The lockdown regulations}

After the COVID-19 hit the shores of South Africa, and following the exponential spread and the fear of the numbers of death it may cause in the country, Dr Mmaphaka Tau on 15 March 2020, in his capacity as Head of the South African National Disaster Management Centre and in terms of section 23(1) of the Disaster Management Act 57 of 2002 (DMA) categorised the pandemic as a national disaster. ${ }^{6}$ Subsequently, the Minister of Cooperative Governance and Traditional Affairs (COGTA), in terms of section 27 of DMA promulgated Regulations (lockdown regulations) that imposed lockdowns in different spheres and sectors in South Africa. In terms of the regulations, lockdowns are stratified into alert level 1 to alert level 5, with alert level 5 as the strictest. To date, a number of regulations have been made. The first regulations - Regulation 11B94 (hereafter, the Level 5 Regulations) took effect on 26 March 2020 and it governed the level 5 lockdown. The second regulations (hereafter, the Level 4 Regulations) came into force on 1 May 2020 to govern alert level 4 lockdown. The third regulation (hereafter, the Level 3 Regulations) came into force on 1 June 2020, and it relates to alert level 3. A number of other regulations have further been made, but their provisions are largely the same with those already mentioned.

Section 11B (i) and (ii) of the Level 5 Regulation and section 24 (1) of the Level 4 Regulations provides that any place or premises normally open to the public where religious and cultural or similar activities take place are to be closed during the period of the lockdowns. Curfews were also placed between $8 \mathrm{pm}$ and $5 \mathrm{am}$ in terms of the two regulations. Section 18 of the Level 4 Regulations specifically permits attendance at funerals during the time of the lockdown, but limits the attendance to 50 people and specifically states that "no night vigil shall be held". It also further requires that "all safety measures are strictly adhered to".

The above provisions mean that worship places like churches, synagogues and mosques were closed for worships during the day and at night in alert Levels 4 and 5 Regulations. It further means that individuals may also not invite any other person to their home for prayer, worship, cell group meetings, to anoint the sick with oil or pray for healing for them, etc. However, in the alert Level 3 Regulations, the ban on religious gatherings was lifted subject to adherence to some protective protocols. 
The regulations were further relaxed in 2021 and people started to become lax about observance of COVID-19 hygiene protocols. In May 2021, nine people who form part of a small Uniting Reformed Church in Vredendal, in the Western Cape, succumbed to COVID-19 complications. The church reopened when COVID-19 restrictions were eased, but with infections rising it has closed its doors again (Masweneng, 2021).

March and April 2021 saw coronavirus infections continue to rise in South Africa, which has prompted the South African government in the beginning of May 2021 to consider introducing additional measures in order to stave off a third wave. The original Alert level 2 was in place from 18 August to 20 September 2020. A new adjusted Alert level 2 was put in place from 31 May 2021. ${ }^{8}$ In terms of the movement of persons, the regulations introduced a closing time for all venues hosting faith-based, or religious gatherings to $22 \mathrm{H} 00$. All faith-based or religious gatherings are permitted but limited to 100 persons or less for indoor venues and 250 persons or less for outdoor venues. If the venue is too small to hold the prescribed number of persons observing a distance of at least one and a half metres from each other, then not more than $50 \%$ of the capacity of the venue may be used, subject to strict adherence to all health protocols and social distancing measures.

Attendance of a funeral is further limited to 100 persons and not more than $50 \%$ of the capacity of the venue may be used, subject to strict adherence to all health protocols and all persons maintaining a distance of one and a half metres from each other. The regulations also prohibit night vigils and after-funeral gatherings, including "after-tears" gatherings. During a funeral, a person must wear a face mask and adhere to all health protocols and social distancing measures. The duration of a funeral is restricted to a maximum of two hours.

\section{Responses to the regulations}

Various groups have reacted differently to the lockdown regulations. For instance, immediately after the alert Level 5 Regulations that introduced "the strictest lockdowns" was announced, most religious organisations appear to accept it as a laudable step by the state to guard the inhabitants of the country against the virus. But some people considered the total and a blanket ban on religious gathering as unreasonable and unconstitutional given that funerals with a maximum of 50 persons were allowed. The state and those who welcome the ban on religious gatherings justify the ban on a number of grounds. First, it is argued that the ban was imposed on all religions; it therefore passes the constitutional test of non-discrimination. Second, there were no effective measures to manage the risk or to prevent the spread of the infection and the possible numbers of death that may occur at the outbreak of the virus in the country. The ban is thus to allow the state to build up an extensive public health response for the anticipated surge of infections (Swain, 2020a). Third, the ban followed similar measures adopted 
by other countries. Furthermore, the purpose of the ban was to curb the spread of the virus in order to save lives. Akin to this is that the ban is to allow citizens to access the constitutionally entrenched rights to health care and an environment that is not harmful.

Those that oppose the ban on religious gathering have also predicated their position on a number of grounds, which include first, given that a person's faith and the manifestation thereof is central to their dignity as a human being, the blanket ban of any form of religious gathering (except for a limited waiver for funerals) is unfair and prejudicial to religious adherents. It also violates their essential humanity (Barmania and Reiss, 2020; Swain, 2020a). Further, given the religiosity of most South Africans, to think that people's spiritual needs are not paramount at a time like this is unreasonable, especially that many are isolated, lonely, and may have lost loved ones or jobs, and are fearful of what the future holds. In fact, for a great many people being a part of a religious body at a time like this is a source of healing, a mode of alleviating suffering and their only lifeline. Some religionists have further argued that the ban had created, anxiety, fear and mental suffering and "spiritual depression" on their adherents (Kowalczyk et al., 2020; Pillay, 2020). Furthermore, throughout history, the religious community has typically been at the forefront of the response to the ravages of disease. Apart from offering fervent and continual prayers for the government and those suffering in the communities, it also offers practical service, spiritual counsel and support (Swain, 2020a). Shutting down religious gathering in a country where faith is deeply woven into the fabric of the society is arbitrary and irrational (Swain, 2020b). Also very related is that some religionists believe the current pandemic is a punishment from God due to the human sinfulness, and it is in worship places that many will seek the face of God for forgiveness and get divine healing (Ozalp, 2020). Thus, the blanket ban on religious activities overlooks the unique contribution of the religious community (Chothia, 2020). Second, it is posited that there are various comparable diseases plaguing the country like tuberculosis, influenza, and so on, for which no worship centre is closed, restricting all religious gatherings at this time is therefore an overreaction. Thirdly, it is argued that if the lockdown could be relaxed for funerals to be held, taxi and grocery stores to operate, it is unreasonable not to allow worship places to open subject to taking precautionary measures to avoid the infection (Chothia, 2020b; Pillay, 2020).

Furthermore, the legality and constitutionality of the lockdown regulations banning religious activities have been challenged in the court, and some are still reportedly about to go to court (Mokhoali, 2021; SABC, 2021; Shange, 2021). But so far, the courts have not been consistent in their rulings on this issue. The remainder of this section will summarise the facts and rulings of two case examples: Mohamed $v$ The President of the Republic of South Africa (Mohamed) ${ }^{9}$ and De Beer $v$ The Minister of Cooperative Governance and Traditional Affairs (De Beer). ${ }^{10}$ 


\section{Mohamed case}

The applicants are Imams and worshippers at a mosque managed by the third applicant. The applicants asked the court to, among other things, declare the provision of the lockdown regulations, which provides for a blanket ban on religious gatherings as overbroad, excessive and unconstitutional to the extent that it fails to allow congregational worship; to allow "an exception" to be made for them to gather and worship under certain conditions; that the respondent be ordered to amend the regulations to permit movement of persons between their residence and places of worship on such reasonable conditions as the court deems appropriate; and that the third applicant be allowed to conduct each of the five daily prayers for a congregation limited to 20 people each under certain strict sanitary precautions.

In the presentation of their case, the applicants submitted that they accepted that the lockdown regulations were rational and a permissible response to the COVID-19 pandemic, they nevertheless argued that their religious obligations are suffering serious and egregious inroads by the lockdown. They posited that it is obligatory for them to perform the five daily prayers in congregation and at mosque even in the face of the COVID-19 pandemic. Accordingly, they claim that the lockdown regulations violate their constitutional rights to freedom of movement, freedom of religion, freedom of association (including religious association) and the right to dignity. Their argument is that if the government could frame some exceptions to the present rule such as for funerals and for taxis to carry $75 \%$ of their usual passenger load, they should be able to do so for purposes of congregational worship as well.

In response, the respondent posited that indeed the lockdown regulations imposed severe restrictions on every person's constitutional rights and particularly those regarding movement and association. However, those limitations are both reasonable and necessary given the suffering and threat that COVID-19 poses to human life, dignity and access to healthcare. The respondent submitted that the regulations encompass a serious limitation of rights, but are justified to protect the rights to life, access to healthcare, an environment that is not harmful to one's health and wellbeing, and the right to dignity that are entrenched in the Constitution.

In her ruling, Neukircher $\mathbf{J}$ held that the application is about whether the state's refusal to craft an exemption permit to allow for congregational religious worship, is reasonable and justifiable in terms of the provision of the Constitution. In her limitation analysis in terms of section 36 of the Constitution, the court held that for the lockdown regulations to constitute a constitutional limitation, the government needs not to show that they will invariably achieve their objections of stemming the COVID-19 pandemic, it is sufficient if they show that the lockdown regulations are a rational measure designed to achieve that end. She held that the restriction was neither unreasonable nor unjustifiable on the basis that the blanket ban was not 
selective, discriminatory or against a particular religion. She further held that the current pandemic calls for every citizen "in the name of the greater good" and in the spirit of Ubuntu to make sacrifices to their fundamental rights.

This approach seemed sensible, especially given the fact that a church gathering in Kwasizabantu in KwaZulu-Natal in December 2020, which was attended by more than 2,000 people, resulted in at least 48 COVID-19 infections in the province (Nombembe, 2020). At the same time, the Roman Catholic Diocese of Mariannhill, west of Durban, has confirmed that nine nuns, who belonged to Daughters of Saint Francis in Port Shepstone, Mariannhill Diocese that have succumbed to COVID-19. All the affected nuns had attended a church function in the past two weeks (Mhlongo, 2020).

\section{De Beer case}

The applicants in this case claimed, among other things, that the declaration of the national state of disaster and all the lockdown regulations promulgated to curb the spread of COVID-19 are unconstitutional, unlawful and invalid; that all the gatherings be declared lawful alternatively be allowed subject to certain condition. It is apposite to state that at the time the ruling in this case was delivered on 2 June 2020, the latter relief has, to an extent, been overtaken by events since the alert Level 3 Regulations that came into force on 1 June 2020 allows religious gatherings, subject to certain conditions. The applicants did not challenge the categorisation of the pandemic as a national disaster; rather they attacked the rationality or constitutionality of the regulations. This is unlike in the Mohamed case where the claimants accepted that the regulations were rational and a constitutionally permissible response to the COVID-19, but only asked for an exception. To justify their claim, the applicants in this case contended that the state's response to the pandemic was irrational and constitute an overreaction. They further contended that in terms of section 59(1) and (4) of the DMA. They were unlawful because the minister did not obtain the approval of the National Council of Provinces prior to the promulgation of the regulations. But this argument was rejected by the court on the ground that the provision is inapplicable in the instant case. In its ruling, the court emphasised that where the power to make a specific regulation is exercised as in the instant case, the regulation made must be rationally related to the purpose for which the power was conferred (this is called the rationality test). The question the court asked was: is there a rational connection between the intervention and the purpose for which it was taken? In construing the rationality test, the court submits that "it is not to determine whether some means will achieve the purpose better than others, but only whether the means employed are rationally related to the purpose for which the power was conferred." To the court, if the means employed to achieve the purpose are disconnected and 
irrational, then they will be unconstitutional and not permissible limitation in terms of section 36 of the Constitution.

The court used some illustrations to evaluate the rationality of the regulations. For instance, it reasoned that the provisions of the regulations that prohibited religious leaders and people (who are willing to take prescribed precautions) to leave their homes to visit and support their loved ones on a deathbed, but allowed them to attend the funeral of the loved one who is departed who needs no support is not rational. The court also observed that a total blanket ban on gathering that implicates the observance of religious vigil for the dead but allows 50 people for a funeral is also not rational. In summary, the court highlighted that the lockdown regulations, including the alert Level 3 Regulations, are replete with instances of sheer irrationality. On the final analysis, the court held that although the Minister's declaration of a national state of disaster in terms of the DMA in response to pandemic is rational, the lockdown regulations do not satisfy the rationality test. Also, their limitations to the Bill of Rights are not justifiable in an open and democratic society based on human dignity, equality and freedom. The court therefore declared them unconstitutional and invalid. The government has rejected this judgment and indicated its intention to appeal it (Rabkin, 2020).

\section{Findings and conclusion}

Although the court attempted to distinguish the facts of Mohamed from the De Beer on the ground that the applicants in the former accepted the rationality of the lockdown regulations which the latter did not accept, the questions for determination in the two cases are essentially the same. The questions bother on the constitutionality of the lockdown regulations. We are of the view that the decision in Mohamed represents the true position of the law. The fact is that no right is absolute. The restriction placed on religious gathering is legitimately permissible given the circumstances of the current pandemic and the fact that people can be exposed to risk in large gatherings. The COVID-19 pandemic presents a "deep health crisis" to the country and the effort to curtail the same in the way the government has done will be legitimate. Although the South African approaches in dealing with the pandemic might have been at the expense of the livelihood of the people, they are based on saving lives and preserving livelihoods.

As for the De Beer judgment, it lacked cogency and appears not to deal thoroughly enough with the issues. Some other commentators have similarly argued that the judgment of De Beer may not be able to stand the scrutiny of the higher court if it is appealed (Comins, 2020; Shange, 2020). Notwithstanding this view, Mohamed and De Beer cases, as well as other cases that have challenged the validity of the lockdown regulation raise some important issues and positive outcomes. 
First, the increased number of lawsuits relating to religious ban reiterates the widely held view that religious institutions are forces to reckon with in state governance in South Africa and most African countries (Agbiji, 2015; Mbiti, 1990). It further reinforces the assertion that freedom of religion is one of the most controversial of all human rights and a potent source of social conflict (Cheadle et al., 2002), and therefore, it should be well managed.

Second, the cases reveal some vacuum and lacunae in the extant legislation that deal with the management of a pandemic in the country, which perhaps had not been subject of court or public scrutiny prior to the outbreak of this present pandemic. The court in De Beer observed this point when it stated "there is no existing legislation and contingency arrangement to adequately manage COVID-19." The implication of such vacuum is that state government would have to promulgate new regulations in a hurry and this may create a tendency of making the state to promulgate arbitrary rules or rules may lead to "unintended" interference with the guaranteed human rights. And this may further open the gate of litigation against the state. For instance, in the De Beer case, the court and the respondent (the state) confirmed that there were many concurrent similar cases challenging the lockdown regulations in other jurisdictions of the court. Akin to this is that the state should not in the name of a pandemic assume that it can limit human rights. The state should always prioritize the realisation and protection of human rights at all times.

In conclusion, the increased number of lawsuits is a signal to the government that citizens could go to court to challenge the limitations of their rights or seek clarity on the rationale behind the lockdown regulations and their constitutionality. This is a sign of a flourishing democracy where the people keep the state in check, even during a national state of disaster. Accordingly, the state must be conscious that in a constitutional democracy like South Africa, any legislation by the government must be rational and must justifiably limit the rights of citizens. Even though the decision of the De Beer is likely to be successfully appealed, the judgment, at least emphasises the fundamental principle that every exercise of state power, whether legislative or executive cannot be arbitrarily conducted; it must be subject to the constitution and give respect to the bill of rights. Put differently, in the exercise of public power or performance of a public function, there is the need for state apparatus to self scrutinize in order to ensure the legality and constitutional compliance thereof. Furthermore, South African religious institutions have been widely recognised as major civil institutions that play a role in the provision of social services to complement the state effort (Goodchild, 2016; Koegelenberg, 2001). Even despite the limitation that was placed on religious gatherings during this time, religious communities have reportedly played, and are still playing an important role in alleviating the effects of the pandemic on the citizens. For example, the religious communities were at the forefront of alleviating the suffering of citizens in the face 
of illness and mobilizing resources (Swain, 2020a) - spiritual, monetary and psychological to support the needy, as well as calming an already restless society (Barmania and Reiss, 2020; Maromo, 2020; Nzwili, 2020; Swain, 2020a). Accordingly, for religious communities to continue to play a role in the provision of social services, it is expedient that the state respect and protect their institutional religious rights; such rights should be limited only in exceptional circumstances, as illustrated by Mohamed.

\section{Notes}

1 Religion in this context refers to any particular system of faith and worship, such as Christianity, Islam, Buddhism, African traditional religion, and so on.

2 De Beer $v$ The Minister of Cooperative Governance and Traditional Affairs (Case No: 21542/2020. Judgment delivered on 2 June 2020); Moela v Habib(Case No. 2020/9215, Judgment delivered on 23 March 2020); Khosa v Minister of Defence and Military Veterans and of Police (Case No. 21512/2020, Judgment delivered on 15 May 2020); Mohamedv The President of the Republic of South Africa (Case No: 2140/20 Judgment delivered on 30 April 2020).

3 Section 9(3) provides: "The state may not unfairly discriminate directly or indirectly against anyone on one or more grounds, including race, gender, sex, pregnancy, marital status, ethnic or social origin, colour, sexual orientation, age, disability, religion, conscience, belief, culture, language and birth." Emphasis added.

4 Section 31(1) provides: "Persons belonging to a cultural, religious or linguistic community may not be denied the right, with other members of that community - (a) to enjoy their culture, practise their religion and use their language; and (b) to form, join and maintain cultural, religious and linguistic associations and other organs of civil society.

5 Section 185(1) provides for the functions of the Commission for the Promotion and Protection of the Rights of Cultural, Religious and Linguistic Communities to among others things, "promote respect for the rights of cultural, religious and linguistic communities." Emphasis added.

6 The Classification of a National Disaster published in government Notice No. 43096 of 15 March 2020.

7 The night vigil is a religious and cultural practices usually observed by the family of the deceased to honor the deceased.

8 Gazette 43620 of 17 August 2020) as amended by Gazette 44642 of 30 May 2021.

9 Case No: 2140/20; Khosa v Minister of Defence and Military Veterans and of Police (Case No. 21512/2020). The case was decided by Fabricius J on 15 May 2020.

10 Case No: 21542/2020.

\section{References}

Agbiji, O.M. and I. Swart. (2015) 'Religion and Social Transformation in Africa: A Critical and Appreciative Perspective' Scriptura, 114(1), pp. 1-20.

Barmania, S. and M.J. Reiss. (2020) 'Health Promotion Perspectives on the COVID-19 Pandemic: The Importance of Religion' Global Health Promotion, 28(1), pp. 15-22.

Cheadle, M.H., D.M. Davis and N.R.L. Hayson. (2002) South African Constitutional Law: The Bill of Rights. Durban: Butterworths. 
Chothia, A. (2020a) 'Police Raid Mosque, Arrest Men for Gathering during Ramadan' The South African, 25 April. Available at: https://www.thesouthafrican.com/ news/police-arrest-men-mosque-lockdown-video/ (Accessed: 28 April 2020).

Chothia, A. (2020b) 'Reformed Churches Ask for One Gathering on Sundays During Lockdown' The South African, 28 April. Available at: https://www.thesouthafrican.com/news/reformed-churches-gathering-during-lockdown/ (Accessed: 30 April 2020).

Comins, L. (2020) 'Mixed Views on Lockdown Judgment' The Mercury, 4 June. Available at: http://themercury.newspaperdirect.com/epaper/showarticle.aspx?article $=1764 \mathrm{~b} 401-6 \mathrm{a} 7 \mathrm{e}-430 \mathrm{~b}-99256 \mathrm{~d} 9 \mathrm{aleace} 631 \& \mathrm{key}=$ tuf NkZaqqzutAhv2E \% 2bU90g\%3d \%3d\&issue $=64032020060400000000001001$ (Accessed: 3 July 2020).

Constitution of the Republic of South Africa, 1996.

Dinstein, Y. (1992) 'Freedom of Religion and Religious Minorities', in Dinstein, Y. (ed). The Protection of Minorities and Human Rights. Netherlands. Springer.

Evans, C. (2001) Freedom of Religion under the European Convention on Human Rights. Oxford: Oxford University Press.

Goodchild, E. (2016) Best Corporate Governance Practices: Financial Accountability of Selected Churches in the Free State Province (LLM thesis, University of the Free State).

Govindjee, A. (2016) 'Freedom of Religion, Belief and Opinion', in Govindjee, A (ed). Introduction to Human Rights Law. 2 ed. Durban: LexisNexis.

Koegelenberg, R.A. (2001) 'Social Development Partnership between Religious Communities and the State: Perspectives from the National Religious Association for Social Development' Journal of Theology for Southern Africa, 110, pp. 97-109.

Kowalczyk, O., K. Roszkowski, X. Montane, W. Pawliszak, B. Tylkowski and A. Bajek (2020) 'Religion and Faith Perception in a Pandemic of COVID-19' Journal of Religion and Health 59, 2671-2677.

Maromo, J. (2020) 'Religious Leaders Asked to 'Practise Charity', Help the Poor during Covid-19 Lockdown' IOL, 15 April. Available at: https://www.iol.co.za/ news/politics/religious-leaders-asked-to-practise-charity-help-the-poor-duringcovid-19-lockdown-46721704 (Accessed: 30 April 2020).

Masweneng, K. (2021) 'Nine Congregants Die as Covid-19 Sweeps Through Vredendal Church' Times Live, 1 June 2021. Available at: https://www.timeslive. co.za/news/south-africa/2021-06-01-nine-congregants-die-as-covid-19-sweepsthrough-vredendal-church/ (Accessed: 4 June 2021).

Mbiti, J.S. (1990) African Religious and Philosophy. Portsmouth: Heinemann.

Mhlongo, F. (2020) 'Ninth Death Reported at Durban's Roman Catholic Diocese amid COVID-19' SABC News, 21 December. Available at: https://www.sabcnews. $\mathrm{com} / \mathrm{sabcnews} /$ ninth-death-reported-at-durbans-roman-catholic-diocese-amidcovid-19/ (Accessed: 4 June 2021).

Mokhoali, V. (2021) 'SANCF Takes Govt to Court Over Decision to Ban Religious Gatherings' Eyewitness News, 11 January, Available at: https://ewn. co.za/2021/01/16/sancf-takes-govt-to-court-over-decision-to-ban-religiousgatherings (Accessed: 30 January 2021).

Mwai, P. (2021) 'Coronavirus: When Will South Africa Start Vaccinating?' BBC News, 10 February. Available at: https://www.bbc.com/news/world-africa-55675806 (Accessed: 13 March 2021). 
Nombembe, P. (2020) 'Church Gathering Ignites 48 Covid-19 Cases as Virus Spreads in KZN' Times Live, 12 December. Available at: https://www.timeslive. co.za/news/south-africa/2020-12-20-church-gathering-ignites-48-covid-19-casesas-virus-spreads-in-kzn/ (Accessed: 4 June 2021).

Nzwili, F. (2020) 'African Church Leaders Work to Curb Domestic Abuse During Lockdown' CNS News, 19 May. Available at: https://www.catholicnews.com/services/englishnews/2020/african-church-leaders-work-to-curb-domestic-abuseduring-lockdown.cfm (Accessed: 30 June 2020).

Ozalp, M. (2020) 'How Coronavirus Challenges Muslims' Faith and Changes their Lives' The Conversation 2 April. Available at: https://theconversation.com/howcoronavirus-challenges-muslims-faith-and-changes-their-lives-133925 (Accessed: 30 April 2020).

Pillay, K. (2020) 'Muslim Groups Plead with President to Relax Regulations for Daily Prayers' Mercury News, 6 April. Available at: https://www.iol.co.za/mercury/news/muslim-groups-plead-with-president-to-relax-regulations-for-dailyprayers-46315332 (Accessed: 30 May 2020).

Quashigah, K. (2014) 'Religion and the Republican State in Africa: The Need for a Distanced Relationship' African Human Rights Law Journal, 14, pp. 78-92.

Rabkin, F. (2020) 'Dlamini-Zuma Seeks to Appeal the Judgment that Set Aside Lockdown Regulations' Mail and Guardian' 9 June. Available at: https://mg.co. za/politics/2020-06-09-dlamini-zuma-seeks-to-appeal-the-judgment-that-setaside-lockdown-regulations/ (Accessed: 30 June 2020).

Robertson, M (ed) (1991) Human Rights for South Africans. Oxford: Oxford University Press.

SABC. (2021) 'Freedom of Religion SA Goes to Court to Demand Lifting of Religious Gatherings Ban' $S A B C$ News, 28 January. Available at: https://www. sabcnews.com/sabcnews/freedom-of-religion-sa-goes-to-court-to-demandlifting-of-religious-gatherings-ban/ (Accessed: 30 January 2021).

Shange, N. (2020) 'Lockdown Judgment Should Have Been More Concise and Persuasive: Legal Experts' Times Live, 3 June https://www.timeslive.co.za/news/ south-africa/2020-06-03-lockdown-judgment-should-have-been-more-conciseand-persuasive-legal-experts/ (Accessed: 30 June 2020).

Shange, N. (2021) 'Doors Might Be Open, But Church Council Wants Government Stopped from Ever Shutting them Again' Times Live, 2 February. Available at: https://www.timeslive.co.za/news/south-africa/2021-02-02-doors-might-be-openbut-church-council-wants-government-stopped-from-ever-shutting-them-again/ (Accessed: 30 February 2021).

Sullivan, W.F., E.S. Hurd, S. Mahmood and P.G. Danchin (eds), 2015. Politics of Religious Freedom. Chicago: University of Chicago Press.

Swain, M. (2020a) 'Lockdown Regulations: What about the Religious Community?' FOR SA, 14 May. Available at: https://forsa.org.za/lockdown-regulations-whatabout-the-religious-community/ (Accessed: 30 June 2020).

Swain, M. (2020b) 'COVID-19 Lockdown: A Case for Limited Exemption for Religious Organisations' FOR SA, 16 April 2020. Available at: https://forsa.org.za/ covid-19-lockdown-a-case-for-limited-exemption-for-religious-organisations/ (Accessed: 30 April 2020).

Tsotetsi, D. (2020) 'CHANGE Calls for Reopening of Religious Gatherings During Level 3 Lockdown' $S A B C$, News 6 May. Available at: https://www.sabcnews. 


\section{Helena Van Coller and Idowu A. Akinloye}

$\mathrm{com} / \mathrm{sabcnews} / \mathrm{change-calls-for-reopening-of-religious-gatherings-during-level-}$ 3-lockdown/ (Accessed: 30 May 2020).

Van der Schyff, G. (2003) 'Freedom of Religious Autonomy as an Element of the Right to Freedom of Religion', Journal of South African Law, 3, pp. 512-539.

WHO (2020a) 'Statement on the Second Meeting of the International Health Regulations (2005) Emergency Committee Regarding the Outbreak of Novel Coronavirus (2019-nCoV)'. Available at: https://www.who.int/news-room/ detail/30-01-2020-statement-on-the-second-meeting-of-the-internationalhealth-regulations-(2005)-emergency-committee-regarding-the-outbreak-ofnovel-coronavirus-(2019-ncov) (Accessed: 30 April 2020).

WHO (2020b) 'WHO Director-General's Opening Remarks at the Media Briefing on COVID-19'. Available at: https://www.who.int/dg/speeches/detail/who-directorgeneral-s-opening-remarks-at-the-media-briefing-on-covid-19---11-march-2020. (Accessed: 30 April 2020).

Worldometer. (2021) 'COVID-19 Coronavirus Pandemic' Available at: https://www. worldometers.info/coronavirus/? (Accessed: 2 June 2021). Nam voluptaqui officid que in corro consed quossi de quid quid explani mporerit oditent. 